\title{
Perbandingan Konsentrasi IL-4 Air Mata Penderita Alergi Okuli pada Pemberian Pemirolast potassium 0,1\% dan Cromolyn sodium 4\%
}

\section{Comparison of IL-4 Concentration in the Tears of the Ocular Allergic Patients between the Treatment of Pemirolast potassium 0,1\% dan Cromolyn sodium 4\%}

\author{
Nurul Elyana, Rosy Aldina \\ Laboratorium Ilmu Kesehatan Mata Rumah Sakit Umum Dr. Saiful Anwar Malang
}

\begin{abstract}
ABSTRAK
Interleukin 4 merupakan sitokin yang berperan dalam patofisiologi alergi okuli. Penelitian ini dilakukan untuk mengetahui penurunan konsentrasi IL-4 dan perbedaan penurunan konsentrasi IL-4 air mata penderita alergi okuli sesudah diterapi dengan pemirolast potassium 0,1\% dan cromolyn sodium 4\%. Desain uji klinis acak tersamar ganda dilakukan pada 32 sampel penderita alergi okuli yang dibagi menjadi dua kelompok, yaitu 16 subjek yang mendapatkan tetes mata pemirolast potassium 0,1\% dan 16 sampel yang mendapatkan tetes mata cromolyn sodium $4 \%$. Air mata penderita diambil dua kali untuk dilakukan pemeriksaan konsentrasi IL-4, yaitu saat datang dan satu minggu setelah terapi. Konsentrasi IL-4 diperiksa menggunakan ELISA. Analisa data dengan uji $t$ berpasangan dan uji $t$ tidak berpasangan. Pada kelompok pemirolast potassium terdapat penurunan signifikan $(p<0,001)$ rata-rata konsentrasi IL-4 sebelum pemberian $(24,65 \pm$ SD $2,04 \mathrm{pg} / \mathrm{ml})$ dan sesudah pemberian $(20,17 \pm S D 2,34 \mathrm{pg} / \mathrm{ml})$. Penurunan IL-4 yang signifikan $(p<0,001)$ juga didapat pada kelompok cromolyn sodium dengan rata-rata konsentrasi IL-4 awal 23,50 \pm SD 0,95 pg/ml menjadi 22,51 \pm SD $1,07 \mathrm{pg} / \mathrm{ml}$. Penurunan konsentrasi IL-4 pada kelompok pemirolast potassium $(4,47 \pm \mathrm{SD} 1,74 \mathrm{pg} / \mathrm{ml})$ secara signifikan $(p<0,001)$ lebih besar dibanding kelompok cromolyn sodium $(0,99 \pm S D 0,50 \mathrm{pg} / \mathrm{ml})$. Dapat disimpulkan pemberian pemirolast potassium $0,1 \%$ atau cromolyn sodium $4 \%$ dapat menurunkan konsentrasi IL-4 air mata dengan penurunan lebih besar pada pemberian pemirolast potassium $0,1 \%$.
\end{abstract}

Kata Kunci: Alergi okuli , cromolyn sodium 4\%, konsentrasi IL-4 air mata, pemirolast potassium 0,1\%

\begin{abstract}
Interleukin 4 is one of the sitokin that plays important role in ocular allergic. This research was aimed to evaluate the decreasing concentration of IL-4 and differences of decreasing IL-4 concentration between the tears of ocular allergic patients treated with pemirolast potassium $0,1 \%$ and cromolyn sodium $4 \%$. A double blind randomized clinical trial was performed in 32 patients with ocular allergy divided into two groups, 16 patients received pemirolast potassium $0,1 \%$ and the rest of them received cromolyn sodium $4 \%$. To measure the IL-4 concentration the tears were taken twice in the first day and one week after treatment. IL-4 concentration was evaluated using ELISA. Data were analized using paired t test and independent $t$ test. There was a significant reducing of IL-4 concentration $(p<0,001)$ in pemirolast potassium group from $24,65 \pm 2,04 \mathrm{pg} / \mathrm{ml}$ before treatment into $20,17 \pm 2,34 \mathrm{pg} / \mathrm{ml}$ after treatment. A significant reducing of IL-4 concentration in tears $(p<0,001)$ from $23,50 \pm 0,95 \mathrm{pg} / \mathrm{ml}$ into $22,51 \pm 1,07 \mathrm{pg} / \mathrm{ml}$ also found in cromolyn sodium group. The decreasing concentration on pemirolast potassium group $(4,47 \pm 1,74 \mathrm{pg} / \mathrm{ml}$ ) was significantly higher $(p<0,001)$ compared to cromolyn sodium group $(0,99 \pm 0,50 \mathrm{pg} / \mathrm{ml})$. It can be concluded that administration of pemirolast potassium $0,1 \%$ and cromolyn sodium $4 \%$ will reduce the concentration of IL-4 in tears with higher reduction in pemirolast potassium.
\end{abstract}

Keywords : Cromolyn sodium 4\%, IL-4 concentration in the tears, ocular allergic, pemirolast potassium 0,1\%

Jurnal Kedokteran Brawijaya, Vol. 26, No. 3, Februari 2011; Korespondensi : Nurul Elyana. Laboratorium Ilmu Kesehatan Anak, Rumah Sakit Dr. Saiful Anwar Malang, Jl Jaksa Agung Suprapto No. 2, Malang, Tel. (0341) 366242 Email: nurulperdami@yahoo.com 


\section{PENDAHULUAN}

Alergi okuli atau allergic eye disease adalah kumpulan penyakit yang berhubungan dengan reaksi inflamasi alergi pada permukaan mata. Alergi okuli meliputi beberapa subtipe yaitu Seasonal Allergic Conjunctivitis (SAC), Perennial Allergic Conjunctivitis (PAC), Vernal Kerato Conjunctivitis (VKC), Atopic Kerato Conjunctivitis (AKC), Giant Papillary Conjunctivitis (GPC). Prevalensi alergi okuli kurang lebih $20 \%$ dari seluruh penduduk dunia. Gejala klinis alergi okuli adalah gatal, mata berair, rasa terbakar, sekret yang molor, sensasi benda asing, rasa tidak nyaman dan silau dengan derajat yang bervariasi. Perbedaan tipe dari alergi okuli dapat dibedakan berdasar anamnesa dan pemeriksaan klinis. Diagnosa alergi okuli dapat ditegakkan berdasar anamnesis, pemeriksan klinis gejala dan tanda, scrapping konjungtiva, pemeriksaan air mata, skin test, pemeriksaan serologi IgE spesifik (1-3).

Patofisiologi SAC dan PAC terutama berdasar reaksi hipersensitifitas tipe I, sedangkan AKC, VKC dan GPC berdasar reaksi hipersensitifitas tipe I dan IV. Sitokin yang berperan paling utama pada alergi okuli adalah Interleukin-4 (IL-4) (1). Beberapa macam terapi alergi okuli antara lain antihistamin, vasokonstriktor, NSAID, kortikosteroid, stabilisator sel mast, dan imunomodulator (4-5). Pemirolast potassium 0,1\% merupakan stabilisator sel mast generasi baru yang bekerja menghambat ikatan IgE terhadap sel mast, mencegah ikatan alergen dengan kompleks IgE-sel mast, mencegah lepasnya mediator inflamasi dari sel mast, menghambat kemotaksis eosinofil dan netrofil ke jaringan mata (3). Cromolyn sodium $4 \%$ merupakan stabilisator sel mast yang sudah ada sebelumnya bekerja menghambat pelepasan faktor inflamasi dari sel mast, menghambat eosinofil recruitment. Obat ini tidak mampu menghambat pengikatan IgE terhadap sel maupun menghambat interaksi sel mast-lgE dengan antigen spesifik (5-7). Interleukin-4 (IL-4) adalah sitokin yang menginduksi diferensiasi sel T helper naive (Th0 cells) menjadi sel Th2, menginduksi sel Th2 memproduksi IL-4, menstimuli pelepasan IgE dari sel B yang kemudian mengaktifasi sel mast untuk pelepasan mediator inflamasi $(8,9)$. Penelitian ini dilakukan untuk mengetahui penurunan konsentrasi IL4 air mata penderita alergi okuli sesudah terapi pemirolast potassium $0,1 \%$ atau cromolyn sodium $4 \%$ dan untuk mengetahui perbedaan penurunan konsentrasi IL-4 air mata pada penderita alergi okuli yang diterapi pemirolast potassium 0,1\% dibandingkan dengan cromolyn sodium $4 \%$.

\section{METODE}

Uji klinis acak tersamar ganda dilakukan pada populasi penelitian penderita di poliklinik mata bagian Pediatrik Oftalmologi dan bagian Infeksi-Imunologi Rumah Sakit Dr Saiful Anwar Malang. Subjek dipilih dari pasien dengan diagnosis alergi okuli dan memenuhi kriteria inklusi usia 630 tahun, pertama datang dan baru didiagnosa alergi okuli atau penderita alergi okuli lama dengan kriteria eksklusi penderita tidak menetesi obat secara teratur dan tidak datang kontrol pada waktu yang sudah ditentukan, menderita penyakit mata yang lain, menggunakan obat alergi okuli lain. Replikasi yang diperlukan dengan dua perlakuan adalah 16 orang di masing-masing kelompok sehingga diambil 32 orang untuk kedua perlakuan yang diambil dengan consecutive sampling dan dibagi secara

\section{random.}

Alergi okuli adalah kumpulan penyakit yang berhubungan dengan reaksi inflamasi alergi pada permukaan mata dengan diagnosa ditegakkan berdasarkan anamnesis dan pemeriksaan klinis (5). Interleukin 4 (IL-4) merupakan sitokin yang diukur dengan menggunakan ELISA dengan marker Biotin Conjugate IL-4 antibodi, enzim Streptavidin HRP, substrat solution yang memberikan reaksi ikatan berupa warna biru. Warna ini akan dibaca oleh ELISA reader dalam panjang gelombang $450 \mathrm{~nm}$ dan hasil pengukuran berupa konsentrasi dalam $\mathrm{pg} / \mathrm{ml}$ (10). Pengambilan air mata sampel dikumpulkan dan disimpan dalam kurun waktu dua bulan pada suhu $-80^{\circ}$ karena pengukuran konsentrasi IL-4 dari sampel air mata dengan menggunakan ELISA dilakukan dalam waktu bersamaan sehingga sampel air mata dikumpulkan dahulu dan disimpan maksimal dua bulan pada suhu $-80^{\circ}$ karena protein yang terkandung dalam air mata akan bertahan strukturnya pada suhu $-80^{\circ}$ dalam dua bulan. Apabila penyimpanan lebih dari dua bulan maka protein yang terkandung dalam air mata tersebut mulai mengalami kerusakan.

Pemirolast potassium 0,1\% yang digunakan adalah tetes mata Allegysal 0,1\% dalam kemasan botol $5 \mathrm{ml}$ diberikan 2 $x 1$ tetes dalam sehari selama 1 minggu. Satu $\mathrm{ml}$ Allegysal mengandung bahan aktif pemirolast potassium $1 \mathrm{mg}$. cromolyn sodium $4 \%$ yang digunakan adalah tetes mata conver $4 \%$ dalam kemasan minidose diberikan $4 \times 1$ tetes dalam sehari selama 1 minggu, berisi bahan aktif cromolyn sodium 40 milligram dalam $1 \mathrm{ml}$ (5). Perbedaan konsentrasi IL-4 sesudah terapi dimasing-masing kelompok dianalisis dengan $t$ test dependent sedangkan perbedaan penurunan konsentrasi IL-4 setelah terapi antar kelompok dianalisis dengan $t$ test independent menggunakan SPSS 15 for Windows (11).

\section{HASIL}

Karakteristik sampel pada kedua kelompok menunjukkan gambaran yang tidak berbeda signifikan antar kelompok (Tabel 1). Pada kedua kelompok didapatkan usia sebagian besar anak-anak, dengan jenis kelamin laki-laki dan mempunyai riwayat alergi. Hasil uji normalitas dengan menggunakan Kolmogorov Smirnov didapatkan data konsentrasi IL-4 sebelum dan sesudah terapi pada masingmasing kelompok dan penurunannya mempunyai distribusi normal sehingga uji beda dapat dilakukan.

Tabel 1. Karakteristik sampel pada kelompok pemirolast potassium $0,1 \%$ dan cromolyn sodium $4 \%$.

\begin{tabular}{|c|c|c|c|c|c|}
\hline \multirow{2}{*}{$\begin{array}{l}\text { Karakteristik Demografi } \\
\text { 1. Usia }\end{array}$} & \multicolumn{2}{|c|}{$\begin{array}{l}\text { Pemirolast } \\
\text { potassium }(\mathrm{n}, \%)\end{array}$} & \multicolumn{2}{|c|}{$\begin{array}{l}\text { Cromolyn } \\
\text { sodium }(n, \%)\end{array}$} & \multirow{2}{*}{$\begin{array}{r}p \text {-value } \\
0,626\end{array}$} \\
\hline & \multicolumn{2}{|c|}{$9,13 \pm$ SD 3,32 } & \multicolumn{2}{|c|}{$9,68 \pm$ SD 1,25} & \\
\hline \multicolumn{6}{|l|}{ 2. Jenis Kelamin (sex) } \\
\hline Laki-laki & 13 & $40,6 \%$ & 11 & $34,4 \%$ & \multirow{2}{*}{0,422} \\
\hline Perempuan & 3 & $9,4 \%$ & 5 & $15,6 \%$ & \\
\hline \multicolumn{6}{|l|}{ 3. Jenis Kelamin (sex) } \\
\hline$(-)$ & 5 & $15,6 \%$ & 6 & $18,8 \%$ & \multirow{2}{*}{0,714} \\
\hline$(+)$ & 11 & $34,4 \%$ & 10 & $31,3 \%$ & \\
\hline
\end{tabular}


Hasil uji paired sample t-test (Tabel 2) menunjukkan terjadi penurunan konsentrasi IL-4 yang signifikan baik dengan pemberian pemirolast potassium 0,1\% maupun cromolyn sodium $4 \%$. Penurunan konsentrasi IL-4 pada pemberian pemirolast potassium $0,1 \%(4,47 \pm 1,74)$ secara signifikan $(p<0,001)$ lebih besar bila dibandingkan pemberian cromolyn sodium $4 \%(0,99 \pm 0,503)$.

Tabel 2. Perubahan konsentrasi IL-4 (pg/ml) sesudah terapi pemirolast potassium $0,1 \%$ dan cromolyn sodium $4 \%$

\begin{tabular}{llllll}
\hline & \multicolumn{4}{c}{ Evaluasi } & \\
\cline { 2 - 4 } & \multicolumn{3}{c}{ Pre Terapi } & Post Terapi & $p$ \\
\cline { 2 - 4 } & Mean & \pm SD & Mean & \pm SD & \\
\hline & & & & & \\
Pemirolast Potassium $0,1 \%$ & 24,65 & 2,04 & 20,17 & 2,34 & 0,000 \\
Cromolyn Sodium 4\% & 23,50 & 0,94 & 22,51 & 1,07 & 0,000 \\
& & & & & \\
\hline
\end{tabular}

\section{DISKUSI}

Pada sampel penelitian pada kelompok dengan pemirolast potassium $0,1 \%$ maupun cromolyn sodium $4 \%$ menunjukkan bahwa sebagian besar usia anak anak dan berjenis kelamin laki laki. Menurut teori bahwa pada alergi okuli kurang lebih $80 \%$ mengenai usia kurang dari 30 tahun $(4,5)$. Pada penelitian ini sampel sebagian besar usia anak anak dibanding sampel usia dewasa hanya terdapat satu orang yang berusia dewasa yaitu 20 tahun. Pengambilan sampel dilakukan di poli pediatrik oftalmologi dan poli infeksi immunologi dalam dua bulan, sehingga sampel usia dewasa baru didapatkan satu orang dari poli infeksi immunologi. Meskipun ada outlier usia 20 tahun yang hanya satu, tetapi tidak ditemukan perbedaan signifikan rerata usia pada kedua kelompok.

Pada penelitian ini menunjukkan bahwa baik pemirolast potassium $0,1 \%$ maupun cromolyn sodium $4 \%$ berpengaruh terhadap penurunan konsentrasi IL-4 air mata penderita alergi okuli. Dari studi pada penderita alergi okuli dengan immunohistokimia menunjukkan bahwa sel Th2 berperan penting dalam produksi IL-4,

\section{DAFTAR PUSTAKA}

1. Butrus $S$ and Portela Rosaliz. Ocular Allergy: Diagnosis and Treatment. Ophthalmology Clinics of North America. 2005; 18(4): 485-492.

2. Reidy JJ. External Eye Diseases and Cornea in Basic and Clinical Science Course. San Francisco: American Academy of Ophthalmology; 2011-2012; p. 209-211.

3. Manzouri B, Flynn T and Ono S. Allergic Eye Disease : Pathophysiology, Clinical Manifestations and Treatment. In: T Rainhard and D Larkin (Ed). Essentials in Ophthalmology : Cornea and External Eye Disease. Heidelberg: Springer Verlag; 2006; p. 209-222.

4. Kashima MM, Takano Y, Tanaka M, et al. Comparison of 0,1\% Bromfenac Sodium and 0,1\% Pemirolast Potassium for The Treatment of Allergic Conjunctivitis. Japanese Journal of Ophthalmology. 2004; 48(6): 587-590. diferensiasi serta aktifasi sel mast dan eosinofil $(11,12)$. Meningkatnya Th2 akan meningkatkan IL-4, yang kemudian IL-4 menginduksi peningkatan IgE, di mana IgE menginduksi degranulasi sel mast sehingga terjadi pelepasan sitokin (termasuk IL-4) dan mediator inflamasi yang lain. Pada alergi okuli ditemukan IgE dan IL-4 lebih banyak di konjungtiva. Overproduksi IL-4 berhubungan dengan reaksi allergi $(4,12)$.

Pemirolast potassium $0,1 \%$ dan cromolyn sodium $4 \%$ merupakan stabilisator sel mast yang berperan dalam menghambat pengeluaran mediator-mediator reaksi alergi, termasuk pengeluaran IL-4 sebagai salah satu mediator inflamasi yang dikeluarkan sel mast $(4,6,7)$. Penurunan konsentrasi IL-4 setelah diterapi pemirolast potassium $0,1 \%$ atau cromolyn sodium $4 \%$ pada penelitian ini menunjang teori bahwa kedua stabilisator tersebut dapat menghambat pelepasan mediator reaksi inflamasi alergi termasuk IL-4.

Penurunan konsentrasi IL-4 (pg/ml) pada kelompok pasien yang mendapat terapi dengan pemirolast potassium $0,1 \%$ secara signifikan lebih banyak daripada penurunan kadar $\mathrm{IL}-4(\mathrm{pg} / \mathrm{ml})$ pada kelompok yang mendapat terapi dengan cromolyn sodium $4 \%$. Studi klinis yang membandingkan pemirolast potassium $0,1 \%$ dengan nedocromil sodium $2 \%$ menunjukkan bahwa pemirolast potassium dapat mengurangi gejala alergi okuli sebesar $78 \%$ dibandingkan nedocromil sodium sebesar 22\% (7). Shulman (2003) melaporkan bahwa pemirolast potassium $0,1 \%$ lebih efektif dalam mengatasi gejala konjungtivitis allergi daripada nedocromil sodium $2 \%$ (7).

Pada penelitian ini produksi IL-4 oleh sel mast dihambat oleh pemirolast potassium $0,1 \%$ yang mempunyai cara kerja lebih banyak dibandingkan cromolyn sodium $4 \%$. Hal ini mungkin dapat menjelaskan pengaruh pemirolast potassium $0,1 \%$ yang lebih besar dalam menurunkan konsentrasi IL-4 air mata penderita alergi okuli dibanding cromolyn sodium $4 \%$. Penelitian ini membuktikan bahwa penurunan konsentrasi IL-4 air mata secara signifikan setelah pemberian pemirolast potassium $0,1 \%$ atau cromolyn sodium 4\% pada penderita alergi okuli. Pemberian pemirolast potassium 0,1\% memberikan penurunan konsentrasi IL-4 air mata pada penderita alergi okuli lebih besar dibanding cromolyn sodium $4 \%$.

5. Bonini S, Gramiccioni C, Bonini M, and Bresciani M. Practical Approach to Diagnosis and Treatment of Ocular Allergy: A Year Systematic Review. Ophthalmol Clin N Am. 2007; 7(5): 446-449.

6. Gous P and Ropo A. A Comparative Trial of The Safety and Efficacy Of 0.1 Percent Pemirolast Potassium Ophthalmic Solution Dosed Twice or Four Times a Day in Patients with Seasonal Allergic Conjunctivitis. Journal of Ocular Pharmacology and Therapeutics. 2004; 20(2): 139-150.

7. Shulman DG. Two Mast Cell Stabilizers, Pemirolast Potassium 0,1\% and Nedocromil Sodium 2\%, in The Treatment of Seasonal Allergic Conjunctivitis : A Comparative Study. Advances in Therapy. 2003; 20(1): 31-40.

8. Banchereau J and Rybak ME. Interleukin-4 in the Cytokine Handbook. 2nd edition. New York: Academic Press; 2004; p. 99-105. 
9. Izuhara K, Arima K, and Yasunaga S. IL-4 and IL-13: Their Pathological Roles in Allergic Diseases and Their Potential in Developing New Therapies. Current Drugs Target-Inflammation and Allergy. 2002; 1(3): 263-269.

10. Chan DW and Perlstein MT. Immunoassay: A Practical Guide. 2nd edition. New York: Academic Press; 2004; p. 71.

11. Santoso S. Buku Statistik Parametrik. Cetakan ke-4. Jakarta: PT Elex Media Komputindo; 2004; hal. 214.

12. Fujishima H, Shimazaki J, Takeuchi T, Saito I, and Tsubota K. Interleukin-4 and IgE in Seasonal Allergic Conjunctivitis. Ophthalmologica. 1996; 210(6): 325-328. 